\title{
EKSPLORASI DERAJAT RESISTENSI NYAMUK AEDES AEGYPTI TERHADAP INSEKTISIDA JENIS CYPERMETHRIN 0,05\% PADA KASUS DEMAM BERDARAH DENGUE DI KABUPATEN KUDUS TAHUN 2017
}

\author{
Kartika Ayu Lestari ${ }^{*}$ Aris Santjaka**) \\ Jurusan Kesehatan Lingkungan, Politeknik Kesehatan Kemenkes Semarang, \\ Jl.Raya Baturaden KM 12 Purwokerto, Indonesia
}

\begin{abstract}
Abstrak
Demam Berdarah Dengue (DBD) masih menjadi ancaman di provinsi Jawa Tengah dengan tingkat kematian Case Fatality Rate (CFR) lebih tinggi dari rata-rata nasional dan IR 15,81/100.000 penduduk. Kabupaten Kudus pada tahun 2016 termasuk daerah dengan kasus demam berdarah tinggi yaitu mencapai 797 kasus dan jumlah korban meninggal sebanyak 23 orang dengan Insiden Rate (IR) 31,02/100.000 penduduk dan Case Fatality Rate (CFR) 5,36\%. Progam Fogging secara rutin dilakukan untuk menekan incidents rate (IR), akan tetapi endemisitas DBD terus menerus terjadi, salah satu penyebabnya karena resistensi vektor. Untuk itu perlu dilakukannya uji resistensi terhadap insektisida jenis Cypermethrin. Tujuan penelitian ini untuk mengkategorikan derajat resistensi vektor nyamuk Aedes aegypti terhadap insektisida Cypermethrin 0,05\%. Jenis penelitian yang digunakan yaitu deskriptif. Analisis data berupa tabel dan grafik.Hasil penelitian dari 4 Kecamatan yang terdiri dari Kecamatan Kota Kudus, Mejobo, Jati, dan Kaliwungu di Kabupaten Kudus Provinsi Jawa Tengah yang diambil sebagai sampel, secara keseluruhan telah resisten dengan persentase kematian antara 33\%-68\%. Rata-rata prosentase kematian nyamuk Aedes aegypti di Kabupaten Kudus sebesar 45\%. Dengan demikian, bila kematian nyamuk <80\% maka nyamuk tersebut dikategorikan resisten terhadap insektisida Cypermethrin 0,05\%. Kesimpulan bahwa nyamuk Aedes aegypti di Kabupaten Kudus Provinsi Jawa Tengah resisten terhadap insektisida Cypermethrin 0,05\%. Saran yang diberikan ada dua yaitu menaikkan dosis insektisida melalui riset, serta mengganti dengan jenis insektisida yang memiliki target site yang berbeda. Kepustakaan : 28 (2007 - 2017)
\end{abstract}

Kata kunci: Resistensi, Cypermethrin 0,05\%, Aedes aegypti, Kesehatan Lingkungan

\begin{abstract}
Exploration Of Aedes Aegypti Mosquito Resistance Degree Against Cypermethrin 0.05\% Insecticide In Dengue Hemorrhagic Cases In Kudus Regency Year Of 2017 Dengue Hemorrhagic Fever (DHF) remains a threat in Central Java Province with Case Fatality Rate (CFR) higher than the national average and IR 15.81 / 100,000 populations. On 2016 In Kudus Regency the Incidents Rate (IR) was 31.02 / 100.000 and Case Fatality Rate (CFR) was 5.36\% (Health Pocket Book, 2016). Fogging was often conducted to decrease IR, but the DHF endemicity still occurred, one of the triggering factors was vector resistance. So that Cypermethrin resistance investigation was needed The research objective was categorizing Aedes aegypti's resistance degree against cypermethrin 0.05\%.The Research method used was descriptive method. The data analyzed through table and graph. The research result from 4 District in Kudus Regency Central Java Province that taken as research sample shows that the Aedes aegypti's mosquito was resistant with resistance degree ranged from 33\%-68\%. The resistance degree for Kudus Regency with mosquito's mortality rate was less than $80 \%$ in the resistant category.The conclusion drawn was; Aedes aegypti mosquito in Kudus Regency Central Java province was resistant to Cypermethrin 0.05\% insecticide. The proposed suggested were; increase the insecticide dosage through preliminary research, and also replace the insecticide with insecticide that had different target site. Reading List : 28 (2007 - 2017)
\end{abstract}

Keywords: Resistance, Cypermethrin 0,05\%, Aedes aegypti, environmental Health

*) kartikaayu228@gmail.com

**) arissantjaka@gmail.com 


\section{Pendahuluan :}

Pembangunan kesehatan pada hakekatnya adalah upaya yang dilaksanakan oleh semua komponen Bangsa Indonesia yang bertujuan untuk meningkatkan kesadaran, kemauan, dan kemampuan hidup sehat bagi setiap orang agar terwujud derajat kesehatan masyarakat yang setinggi tingginya, sebagai investasi bagi pembangunan sumber daya manusia yang produktif secara sosial dan ekonomis. Keberhasilan pembangunan kesehatan sangat ditentukan oleh kesinambungan antar upaya program dan sektor, serta kesinambungan dengan upaya-upaya yang telah dilaksanakan oleh periode sebelumnya. Undang-Undang Nomor 25 Tahun 2004, tentang Sistem Perencanaan Pembangunan Nasional (SPPN) mengamanatkan bahwa setiap kementerian perlu menyusun Rencana Strategis (Renstra) yang mengacu pada Rencana Pembangunan Jangka Menengah Nasional (RPJMN). (Depkes, 2015)

Kasus Demam Berdarah Dengue (DBD) masih menjadi masalah di ASEAN. Di Indonesia saja, kasus DBD masih fluktuatif , meskipun jumlah kematian sudah bisa ditekan sampai 0,77 persen. Masih tingginya angka kejadian DBD akibat adanya beberapa kendala yakni kondisi lingkungan, perilaku masyarakat, dan belum tersedianya vaksin DBD. Sementara itu perlu adanya budaya $3 \mathrm{M}$ yaitu menguras dan menyikat tempat penampungan air, menutup tempat penampungan air, dan memanfaatkan atau mendaur ulang barang bekas yang bisa menampung air. Sedangkan, 'Plus' adalah mencegah perkembang biakan nyamuk dengan memelihara ikan pemakan jentik, memasang kasa, mengatur ventilasi, serta pencahayaan di dalam ruangan. Sejak tahun 2011, tengah dikembangkan vaksin DBD yang dilakukan di lima negara yaitu Vietnam, Malaysia, Filipina, Thailand, dan Indonesia. Uji coba vaksin ini dilakukan sampai tahun 2016. Di Indonesia, uji coba dilakukan terhadap 2.000 anak di tiga kota yaitu Jakarta, Bandung, dan Denpasar. Jika vaksin dengue bisa ditemukan, bukan hanya Indonesia saja tetapi semua negara di dunia bisa menurunkan angka kejadian DBD sehingga angka kematian akibat DBD pun bisa menurun. (Depkes, 2016)

Data Direktorat Pengendalian Penyakit Tular Vektor dan Zoonosis Kementerian Kesehatan menyebutkan hingga akhir Januari tahun 2016, kejadian luar biasa (KLB) penyakit DBD dilaporkan ada di 12 Kabupaten dan 3 Kota dari 11 Provinsi di Indonesia, antara lain: 1) Provinsi Banten, yaitu Kabupaten Tangerang; 2) Provinsi Sumatera Selatan, yaitu Kota Lubuklinggau; 3) Provinsi Bengkulu, yakni Kota Bengkulu; 4) Provinsi Bali, yaitu Kota Denpasar dan Kabupaten Gianyar; 5) Provinsi Sulawesi Selatan, yaitu Kabupaten Bulukumba, Pangkep, Luwu Utara, dan Wajo; 6) Provinsi Gorontalo, yaitu Kabupaten Gorontalo; serta 7) Provinsi Papua Barat, yakni Kabupaten Kaimana; 8) Provinsi Papua, yakni
Kabupaten Mappi 9) Provinsi NTT, yakni Kabupaten Sikka; 10) Provinsi Jawa Tengah, yaitu Kabupaten Banyumas; 11) Provinsi Sulawesi Barat, yakni Kabupaten Majene. Sepanjang bulan Januari dan Februari 2016, kasus DBD yang terjadi di wilayah tersebut tercatat sebanyak 492 orang dengan jumlah kematian 25 orang pada bulan Januari 2016 sedangkan pada bulan Februari tercatat sebanyak 116 orang dengan jumlah kematian 9 orang. Hasil data tersebut menunjukan adanya penurunan KLB di Indonesia sepanjang bulan Januari-Februari 2016. Kementerian Kesehatan RI mencatat jumlah penderita DBD di Indonesia pada bulan Januari-Februari 2016 sebanyak 8.487 orang penderita DBD dengan jumlah kematian 108 orang. Golongan terbanyak yang mengalami DBD di Indonesia pada usia 5-14 tahun mencapai 43,44\% dan usia 15-44 tahun mencapai 33,25\%. (Depkes RI, 2016)

Setiap tahun insiden demam berdarah di Indonesia cenderung meningkat. Pada akhir Januari tahun 2016, telah dilaporkan terdapat 3.298 kasus DBD yang terjadi dengan jumlah kematian 50 orang. Jika dibandingkan tahun 2015 di tahun 2015 pada bulan Oktober ada 3.219 kasus DBD dengan kematian mencapai 32 jiwa, sementara November ada 2.921 kasus dengan 37 angka kematian, dan Desember 1.104 kasus dengan 31 kematian (Kemenkes, 2016 dalam Laporan BBTKL-PP Yogyakarta).

Dinas Kesehatan Provinsi Jawa tengah melaporkan bahwa penyakit DBD masih tetap menjadi ancaman dengan tingkat kematian Case Fatality Rate (CFR) lebih tinggi dari rata-rata nasional dan IR 15,81/100.000 penduduk. Kasus demam berdarah memang terus mengalami peningkatan di Provinsi Jawa Tengah mencatat sejak Januari hingga 19 Februari 2016 terdapat sebanyak 1.833 kasus demam berdarah dengue (DBD). Dari jumlah tersebut sebanyak 43 orang telah meninggal dunia. Jumlah kasus demam berdarah di Kabupaten Jepara, Jawa Tengah, terhitung sejak awal tahun hingga akhir Maret 2016, tercatat 343 kasus demam berdarah (DB) terjadi. selama tahun 2015 lalu tercatat 1.428 kasus DBD. Dari angka tersebut, sebanyak 11 penderita DBD meninggal. (BBTKL-PP Yogyakarta, 2016)

Penanggulangan penyakit tular vektor adalah selain dengan pengobatan terhadap penderita, juga dilakukan upaya-upaya pengendalian terhadap penderita vektor termasuk upaya mencegah kontak dengan vektor guna mencegah penularan penyakit. Satu di antaranya adalah dengan cara pengendalian vektor dengan menggunakan insektisida. (Kemetrian RI, 2012)

Insektisida yang bisa digunakan untuk memberantas serangga dan vektor banyak jenisnya, ada yang bersifat kontak dan ada yang bersifat sistemik. Insektisida yang bersifat kontak berarti penggunaannya harus langsung kontak dengan sengga, racun akan 
masuk kedalam jaringan tubuh dan akan merusak fungsi fisiologisnya. Sementara insektisida yang bersifat sistemik bekerja sebgai racun lambung atau racun perut yang nantinya akan diserap oleh dinding saluran pencernaan dan akan disalurkan ke sistem safar serangga.

Cypermethrin termasuk insektisida kontak dan sistemik yang akan bekerja sebagai racun lambung atau racun perut. Cypermethrin merukapan insektisida golongan piretroid dan bersifat sangat toksik karena merupakan racun yang menyerang sistem saraf, sehingga serangga atau vektor cepat terbunuh.

Hasil penelitian Irawan Endy P (2016) yang dilakukan di Desa Sidamulih Kecamatan Rawalo Kabupaten Banyumas pada tahun 2016 evaluasi fogging focus (FF) antara sebelum FF dan 3 hari sesudah FF1 terjadi penurunan jumlah nyamuk $40 \%$, meskipun secara statistik tidak bermakna dan 3 hari sesudah FF2 justru terjadi kenaikan 14,5\% ; kenaikan terbesar 17 hari sesudah FF2 yaitu 101,8\%. Artinya sebenarnya fogging tidak efektif sama sekali untuk menekan densitas nyamuk dewasa dan ada indikasi nyamuk telah resistensi.

Hasil penelitian Bina Ikawati, dkk (2015) bahwa nyamuk Aedes aegypti di lokasi penelitian yaitu Kabupaten terpilih di Jawa Tengah telah resisten terhadap malathion 0,8\%, dengan kematian berkisar antar 13,80-61,67\%. Hampir semua telah resisten terhadap Cypermethrin 0,05\% dengan kirasan 1063,33\%, kecuali sampel dari Kabupaten Banjarnegara masih toleran dengan kematian 84,20\%. Sembilan kabupaten pada lokasi survei di Jawa Tengah telah resisten terhadap malathion, delapan kabupaten telah resisten terhadap cypermethrin satu kabupaten yaitu Banjarnegara masih toleran terhadap cypermethrin. Dengan demikian, dari keseluruhan sampel dari tiap kabupaten di provinsi Jawa Tengah hanya Kabupaten Banjarnegara yang masih toleran terhadap cypermethrin.

BBTKL-PP Yogyakarta adalah salah satu unit pelaksana teknis di bidang teknik kesehatan lingkungan dan pemberantasan penyakit di lingkungan Kementerian Kesehatan Republik Indonesia yang berada di bawah koordinasi dan bertanggung jawab kepada Direktur Jenderal Pencegahan dan Pengendalian Penyakit, dengan wilayah kerja D.I. Yogyakarta dan Provinsi Jawa Tengah yang mempunyai tupoksi salah satunya adalah melakukan kajian dan evaluasi pengendalian penyakit menular. Kegiatan ini dilakukan dalam rangka monitoring dan mengetahui sifat resistensi insektisida pada nyamuk dan larva Aedes aegypti vektor penular DBD. Penelitian BBTKL-PP Yogyakarta yang dibantu 3 Orang Mahasiswa Poltekkes Semarang akan dilakukan di 9 Kabupaten yang ada di Jawa Tengah salah satunya yaitu Kabupaten Kudus.

Kabupaten Kudus pada tahun 2016 termasuk daerah dengan kasus demam berdarah tinggi yaitu mencapai 797 kasus dengan jumlah korban meninggal sebanyak 23 orang dengan Insiden Rate (IR) 31,02/100.000 penduduk dan Case Fatality Rate (CFR) 5,36\% (Buku Saku Kesehatan, 2016). Tercatat pada awal tahun 2017 pada bulan Januari sudah terdapat 32 kasus.. Pengumpulan data sekunder (data kasus DBD dan data fogingg) dilakukan untuk menentukan lokasi kegiatan. Kemudian pengumpulan data primer dilakukan dengan cara pengambilan larva nyamuk Aedes aegypti dengan diwakili oleh tiga kecamatan yang terdiri dari dua kecamatan high endemis, satu kecamatan sporadis dan satu kecamatan non endemis. Pada dasarnya setiap daerah harus memiliki data hasil uji resistensi insektisida untuk pemetaan sehingga dapat mengetahui penyebaran penyakit dan menentukan endemis suatu daerah terhadap penyakit Demam Berdarah Dengue.

Berdasarkan latar belakang di atas, penulis tertarik untuk melakukan penelitian dengan Judul "Eksplorasi Derajat Resistensi Nyamuk Aedes aegypti Terhadap Insektisida Jenis Cypermethrin 0,05\% Pada Kasus Demam Berdarah Dengue Di Kabupaten Kudus Tahun 2017” dipilih sebagai topik dalam penyusunan Karya Tulis Ilmiah ini.

\section{Bahan dan Metode :}

Proses penangkapan larva nyamuk Aedes aegypti di empat kecamatan yang mewakili Kabupaten Kudus yaitu Kecamatan Kota Kudus, Kecamatan Mejobo ,Kecamatan Jati, Kecamatan Kaliwungu. Masing-masing Kecamatan diwakili oleh 2 kelurahan dan setiap kelurahan/desa dipilih 50 rumah positif larva. Pengambilan larva nyamuk dilakukan selama 1 hari oleh 10 orang kader setiap kecamatan, dan setiap kader mengumpulkan 10 rumah positif larva nyamuk Aedes aegypti. Sampel larva dari lokasi pengambilan di rearing sampai nyamuk turunan pertama (F1) agar nyamuk cukup untuk pengujian. Kemudian, nyamuk yang digunakan untuk pengujian adalah nyamuk Aedes aegypti dalam keadaan Full feed sebanyak 20-25 ekor. Peralatan yang digunakan untuk uji resistensi menggunakan susceptibility test kit , Impregnated paper berinsektisida Cypermethrin 0,05\%, dan kertas non insektisida. Metode dalam penelitian ini adalah deskriptif yaitu hanya menggambarkan derajat resitensi nyamuk Aedes aegypti di Kabupaten Kudus, Provinsi Jawa Tengah. Analisis data yang digunakan berupa nalisis tabel dan grafik yang kemudian dinarasikan.

\section{Hasil dan Pembahasan :}

Dari uji resistensi yang telah dilakukan didapatkan hasil nyamuk Aedes aegypti pada kelompok terpapar insektisa Cypermethrin 0,05\% rata-rata telah reisiten. Persentase kematian nyamuk Aedes aegypti di 4 kecamatan yaitu, Kecamatan Kota Kudus persentase kematian nyamuk Aedes aegypti dari masing masing ulangan yaitu : ulangan 1 (44\%), ulangan 2 (8\%), dan 
ulangan 3 (64\%) dengan rata-rata persentase kematian 38\%. Dapat dilihat pada tabel dibawah ini :

Tabel 4.7 Hasil Uji Resistensi Nyamuk Aedes aegypti pada Kelompok Terpapar Insektisida Cypermethrin 0,05\%di Kecamatan Kota Kudus

\begin{tabular}{|c|c|c|c|c|c|c|}
\hline No. & $\begin{array}{l}\text { Ulangan } \\
\text { Ke- }\end{array}$ & $\sum$ Nyamuk Uji & $\sum$ Mati & $\sum$ Hidup & $\begin{array}{c}\text { Perentase } \\
\text { Kematian } \\
(\%)\end{array}$ & Keterangan \\
\hline 1 & Ulangan 1 & 25 & 11 & 14 & 44 & Resisten \\
\hline 2 & Ulangan 2 & 25 & 2 & 20 & 8 & Resisten \\
\hline \multirow[t]{2}{*}{3} & Ulangan 3 & 22 & 14 & 8 & 64 & Resisten \\
\hline & Total & 72 & 27 & 42 & 38 & Resisten \\
\hline
\end{tabular}
nyamuk Aedes aegypti dari masing masing ulangan yaitu : ulangan 1 (45\%), ulangan 2 (30\%), dan ulangan 3 (40\%) dengan rata-rata persentase kematian 38\%. Dapat dilihat pada tabel dibawah ini :

Tabel 4.8 Hasil Uji Resistensi Nyamuk Aedes aegypti pada Kelompok Terpapar Insektisida Cypermethrin 0,05\%di Kecamatan Mejobo

\begin{tabular}{ccccccc}
\hline No. & $\begin{array}{c}\text { Ulangan } \\
\text { Ke- }\end{array}$ & $\sum$ Nyamuk Uji & $\sum$ Mati & $\sum$ Hidup & $\begin{array}{c}\text { Perentase } \\
\text { Kematian } \\
(\%)\end{array}$ & Keterangan \\
\hline 1 & Ulangan 1 & 20 & 9 & 11 & 45 & Resisten \\
2 & Ulangan 2 & 23 & 7 & 16 & 30 & Resisten \\
3 & Ulangan 3 & 20 & 8 & 12 & 40 & Resisten \\
\hline & Total & $\mathbf{6 3}$ & $\mathbf{2 4}$ & $\mathbf{3 9}$ & $\mathbf{3 8}$ & Resisten \\
\hline
\end{tabular}

Kecamatan Jati persentase kematian nyamuk Aedes aegypti dari masing masing ulangan yaitu : ulangan 1 (72\%), ulangan 2 (68\%), dan ulangan 3 (64\%) dengan rata-rata persentase kematian 68\%.\%. Dapat dilihat pada tabel dibawah ini :

Tabel 4.9 Hasil Uji Resistensi Nyamuk Aedes aegypti pada Kelompok Terpapar Insektisida Cypermethrin 0,05\%di Kecamatan Jati

\begin{tabular}{ccccccc}
\hline No. & $\begin{array}{c}\text { Ulangan } \\
\text { Ke- }\end{array}$ & $\sum$ Nyamuk Uji & $\sum$ Mati & $\sum$ Hidup & $\begin{array}{c}\text { Perentase } \\
\text { Kematian } \\
(\%)\end{array}$ & Keterangan \\
\hline 1 & Ulangan 1 & 25 & 18 & 7 & 72 & Resisten \\
2 & Ulangan 2 & 25 & 17 & 8 & 68 & Resisten \\
3 & Ulangan 3 & 25 & 16 & 9 & 64 & Resisten \\
\hline & Total & $\mathbf{7 5}$ & $\mathbf{5 1}$ & $\mathbf{2 4}$ & $\mathbf{6 8}$ & Resisten \\
\hline
\end{tabular}

Kecamatan Kaliwungu persentase kematian nyamuk Aedes aegypti dari masing masing ulangan yaitu : ulangan 1 (30\%), ulangan 2 (21\%), dan ulangan 3 (50\%) dengan rata-rata persentase kematian nyamuk 33\%. dilihat pada tabel dibawah ini :

Tabel 4.10 Hasil Uji Resistensi Nyamuk Aedes aegypti pada Kelompok Terpapar Insektisida Cypermethrin 0,05\%di Kecamatan Kaliwungu

\begin{tabular}{ccccccc}
\hline No. & $\begin{array}{c}\text { Ulangan } \\
\text { Ke- }\end{array}$ & $\sum$ Nyamuk Uji & $\sum$ Mati & $\sum$ Hidup & $\begin{array}{c}\text { Perentase } \\
\text { Kematian } \\
(\%)\end{array}$ & Keterangan \\
\hline 1 & Ulangan 1 & 20 & 6 & 14 & 30 & Resisten \\
2 & Ulangan 2 & 24 & 5 & 19 & 21 & Resisten \\
3 & Ulangan 3 & 22 & 11 & 11 & 50 & Resisten \\
\hline \multicolumn{2}{r}{ Total } & $\mathbf{6 6}$ & $\mathbf{2 2}$ & $\mathbf{4 4}$ & $\mathbf{3 3}$ & Resisten \\
\hline
\end{tabular}

Jadi, populasi nyamuk Aedes aegypti di empat kecamatan yang dijadikan sampel di Kabupaten kudus secara keseluruhan memiliki presentase kematian sebesar 45\%, sehingga dapat dikatakan Kecamatan Kaliwungu sudah resisten terhadap insektisida Cypermethrin 0,05\%. Dapat dilihat pada tabel dibawah ini :

Tabel 4.11 Hasil Uji Resistensi Nyamuk Aedes aegypti pada Kelompok Terpapar Insektisida Cypermethrin 0,05\% di Kabupaten Kudus

\begin{tabular}{|c|c|c|c|c|c|c|}
\hline No. & $\begin{array}{c}\text { Nama } \\
\text { Kecamatan }\end{array}$ & $\sum$ Nyamuk Uji & $\sum$ Mati & $\sum$ Hidup & $\begin{array}{c}\text { Persentase } \\
\text { Kematian } \\
(\%)\end{array}$ & Keterangan \\
\hline 1 & $\begin{array}{l}\text { Kota } \\
\text { Kudus }\end{array}$ & 72 & 27 & 42 & 38 & Resisten \\
\hline 2 & Mejobo & 63 & 24 & 39 & 38 & Resisten \\
\hline 3 & Jati & 75 & 51 & 24 & 68 & Resisten \\
\hline \multirow[t]{2}{*}{4} & Kaliwungu & 66 & 22 & 44 & 33 & Resisten \\
\hline & Total & 276 & 124 & 109 & 45 & Resisten \\
\hline
\end{tabular}

Grafik 4.6 Persentase Kematian Nyamuk Aedes aegypti pada kelompok Terpapar di Kabupaten Kudus Tahun 2017

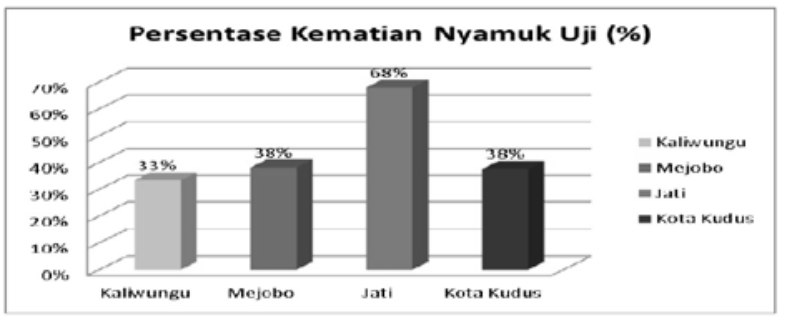

Sedangkan untuk kelompok kontrol dari 4 Kecamatan terdiri dari Kecamatan Kota Kudus, Kecamatan Mejobo, Kecamatan Jati, dan Kecamatan Kaliwungu sebanyak 25 ekor nyamuk yang dijadikan kontrol setelah pengujian dan pengamatan 1x24 jam, 25 ekor nyamuk tersebut masih dalah keadaan hidup. Dapat dilihat pada tabel dibawah ini :

Tabel 4.12 Hasil Uji Resistensi Nyamuk Aedes aegypti pada Kelompok Kontrol di Kabupaten Kudus

\begin{tabular}{clcccc}
\hline No. & $\begin{array}{c}\text { Nama } \\
\text { Kecamatan }\end{array}$ & $\sum$ Nyamuk Uji & $\sum$ Mati & $\sum$ Hidup & $\begin{array}{c}\text { Persentase } \\
\text { Kematian } \\
\text { Nyamuk Kontro } \\
(\%)\end{array}$ \\
\hline 1 & Kota Kudus & 25 & 0 & 25 & 0 \\
2 & Mejobo & 25 & 0 & 25 & 0 \\
3 & Jati & 25 & 0 & 25 & 0 \\
4 & Kaliwungu & 25 & 0 & 25 & 0 \\
\hline
\end{tabular}

Jadi, jika dalam satu Kabupaten terdapat satu titik wilayah atau kecamatan yang telah resisten terhadap insektisida Cypermethrin, maka seluruh kecamatan yang ada di Kabupaten tersebut secara keseluruhan telah resisten terhadap Cypermethrin. Terjadinya resitensi dapat diketahui dari mekanisme resistensi sebagai berikut :

1. Mekanisme fisologis

Mekanisme ini terjadi karena terjadinya perubahan daya absorbs racun menjadi sangat lambat, sehingga mekanisme adaptasi terhadap racun juga lambat, disamping itu terjadi mekanisme deposit insektisida tidak pada jaringan organ vital, percepatan ekskresi, dampaknya respon kematian juga lambat, 
dengan demikian nyamuk terhindari dari kematian secara masif.

\section{Mekanisme Biokimia}

Mekanisme ini terjadi adanya reaksi enzimatik secara kemplek di dalam tubuh nyamuk, dengan mekanisme detoksifikasi yaitu mengurangi insektisida menjadi molekul-molekul yang tidak toksik (Kemenkes RI, 2012). Detoksifikisi ini terjadi karena perubahan action site (target) atau sistem blocking enzym terhadap insektisida pada organ vital seperti syaraf yang dilakukan oleh enzim cholin esterase. Enzim lain yang juga berperan dalam proses reaksi antara lain hidrolase, fosfatase, karboksilamidase. (Ishartadiati K, 2007 dalam Aris Santjaka)

3. Mekanisme perilaku (behavioural reistance) Struktur morfologi nyamuk mempunyai eksoskeleton sedemikian rupa, sehingga insektisida tidak mempunyai eksoskeleton sedemikian rupa, sehingg insektisida tidak mempunyai kemampuan secara maksimal masuk dalam tubuh nyamuk, disamping itu secara alamiah nyamuk cenderung menghindari kontak dengan insektisida saat dilakukan penyemprotan (Kemenkes RI, 2012 dalam Aris Santjaka)

4. Bio molekuler

Biomolekuler melihat resistensi dari sisi yang terjadi pada rangkaian molekul baik dalam sel maupun kromosom. Penyakit yang ditularkan melalui vektor mengalami double burden, beban pertama berupa tekanan di manusia yaitu dengan menggunakan obatobatan, beban kedua terletak di tubuh nyamuk yaitu berupa harus menghadapi jenis insektisida yang sudah dipaparkan dalam waktu yang cukup lama.

Reaksi yang sering terjadi adalah mutasi. Reaksi ini sebenarnya secara alamiah lazim terjadi, yaitu beberapa ikatan protein tersebut. Yaitu beberapa ikatan protein lepas dari ikatan induknya, sehingga ada ruang kosong diantara rangkaian protein tersebut. Disisi lain ada ikatan proten lain yang lepas dan mencari pasangan protein yang sama, maka ruang kosong yang ditinggalkan tadi akan diisi oleh rangkaian protein yang lepas, jika rangkaian protein tersebut dari DNA yang resisten, maka agen tersebut berubah menjadi resisten (transformasi); jenis lain rangkaian protein yang lepas tadi ditangkap oleh bacteriofag atau macrofag yang membawa DNA dari agen lain yang resisten (transduksi); bisa juga dengan carakonjugasi yaitu melalui plasmid (DNA ekstra kromosom), jika ada plasmid R (yang bersifat resistensi) maka plasmid akan masuk dalam sel melalui pilus seks, maka sel tersebut akan berubah menjadi resisten (Giguere S et al, 2013). Hal yang sama juga bis aterjadi pada DNA nyamuk, ini semua menimbulkan switching genom yang menjadikab survival makhluk hidup tetap bertahan. (Aris Santjaka, 2016.

Kategori resistensi didasarkan pada persentase kematian nyamuk uji. Adapun hasil yang didapatkan dari pengujian adalah Kabupaten Kudus setelah dilakukan uji resistensi mendapatkan rata-rata prosentase kematian 45\%. Menurut WHO (2013) bila kematian nyamuk $<80 \%$ maka nyamuk tersebut telah resisten terhadap suatu insektisida jenis tertentu. Jadi, dapat dikatakan nyamuk Aedes aegypti di Kabupaten Kudus telah resisten terhadap insektisida Cypermethrin.

Sedangkan Menurut WHO (2016) sudah berbeda dengan WHO (2013) karena pada WHO (2016) Resistensi telah dibagi menjadi 3 yaitu untuk kematian nyamuk uji kurang dari 90\% dinyatakan resisten tinggi, kematian nyamuk uji 90\%-97,99\% dinyatakan resisten moderat, dan kematian nyamuk uji 98\%-100\% dinyatakan rentan. Jadi, untuk Kabupaten Kudus termasuk dalam resisten tinggi terhadap insektisida Cypermethrin. WHO 2016 secara keseluruhan memiliki prosedur kerja yang sedikit berbeda dengan WHO 2013 sehingga untuk peraturan baru hanya digunakan sebagai pembanding dan informasi baru bagi Kabupaten Kudus.

Nyamuk Aedes aegypti di Kabupaten Kudus yang telah dikategorikan resisten. Menurut WHO 2016, kemampuan nyamuk untuk bertahan hidup terhadap dosis insektisida standar bisa terjadi karena adanya adaptasi secara fisiologis. Sehingga, timbulnya resistensi pada populasi vektor nyamuk tersebut sangat berpengaruh dengan peningkatan kasus Demam Berdarah Dengue.

Tindak lanjut untuk dari reistensi yang terjadi terhadap insektisida cypermethrin 0,05\% adalah dengan cara menaikan dosis insektisida cypermethrin sampai batas toksikologi sebesar $37.5 \mathrm{mg} / \mathrm{kg} / \mathrm{day}$, Bila dengan menaikan dosis nyamuk masih resisten, maka mengganti dengan insektisida dengan jenis target site yang berbeda dan mempelajari bagaimana mekanisme resistensi suatu insektisida.

\section{Kesimpulan :}

1. Nyamuk Aedes aegypti yang mati pada kelompok terpapar insektisida Cypermethrin 0,05\% yaitu Kecamatan Kota Kudus sebanyak 27 ekor, Kecamatan Mejobo sebanyak 24 ekor, Kecamatan Jati sebanyak 51 ekor, dan Kecamatan Kaliwungu sebanyak 22 ekor. Total keseluruhan di Kabupaten Kudus nyamuk Aedes aegypti yang mati ada 124 kor.

2. Nyamuk Aedes aegypti yang mati pada kelompok kontrol sebanyak 0 ekor.

3. Prosentasi kematian nyamuk Aedes aegypti pada kelompok terpapar insektisida Cypermethrin 0,05\% yaitu :

a. Kecamatan Kota Kudus memiliki persentase kematian nyamuk Aedes aegypti sebesar 38\%.

b. Kecamatan Mejobo memiliki persentase kematian nyamuk Aedes aegypti sebesar 38\%.

c. Kecamatan Jati memiliki persentase kematian nyamuk Aedes aegypti sebesar 68\%. 
d. Kecamatan Kaliwungu memiliki persentase kematian nyamuk Aedes aegypti sebesar 33\%.

e. Kabupaten Kudus Provinsi Jawa Tengah untuk Aedes aegypti dari 4 Kecamatan yang diambil sebagai sampel, secara keseluruhan memiliki persentase kematian nyamuk sebesar $45 \%$.

4. Prosentasi kematian nyamuk Aedes aegypti pada kelompok kontrol yaitu 0\%

5. Kategori resistensi nyamuk Aedes aegypti terhadap insektisida Cypermethrin 0,05\% menurut WHO, 2013 masuk dalam kategori resisten

\section{Saran}

Bagi Institusi Pemerintah Dinas Kesehatan Kabupaten Kudus yiatu :

1. Mempertimbangkan untuk menaikkan dosis insektisida atau mengganti dengan jenis insektisida yang mempuntai target site yang berbeda.

2. Mempelajari lebih lanjut tentang mekanisme resistensi yang terjadi pada nyamuk Aedes aegypti terhadap suatu jenis insektisida.

3. Evaluasi secara berkala (3-5 tahunan) terhadap efektivitas insektisida yang digunakan, khususnya di daerah dengan status endemisitas tinggi, agar pengendalian yang akan diterapkan tepat guna, waktu dan sasaran sehingga status toleran tidak menjadi resisten.

4. Melakukan monitoring terhadap penggunaan insetisida dengan memantau efektivitasnya dalam pengendalian nyamuk Aedes aegypti di lokasi endemis DBD.

\section{Ucapan Terima Kasih}

Ucapan terima kasih diucapkan kepada :

1. Bapak Sugiyanto, S.Pd., M.App.Sc, selaku Direktur Politeknik Kesehatan Kemenkes Semarang.

2. Bapak Asep Tata Gunawan, SKM., M.Kes , selaku Ketua Jurusan Kesehatan Lingkungan Purwokerto.

3. Bapak Suparmin, S.ST., M.Kes., selaku Ketua Program Studi Diploma III Kesehatan Lingkungan Purwokerto.

4. Bapak Dr. Aris Santjaka, SKM., M.Kes., selaku Pembimbing Karya Tulis Ilmiah.

5. Bapak Tri Cahyono, SKM., M.Si, selaku Dosen mata kuliah Metodologi Penelitian.

6. Seluruh Dosen dan Staf Program Studi Diploma III Kesehatan Lingkungan Purwokerto yang telah membantu kelancaran proses penulisan Karya Tulis Ilmiah.

7. Bapak Dr. Hari Santoso, SKM., M.Epid, MH.Kes selaku Kepala Balai Besar Teknik Kesehatan Lingkungan dan Pengendalian Penyakit (BBTKLPP) Yogyakarta.

8. Bapak Yohanes Didik Setiawan, selaku kepala bidang Laboratorium Entomologi
9. Bapak Mieng Sutopo, selaku pembimbing di BBTKL-PP Yogyakarta

10. Keluarga tercinta, Bapak Cipto Buntoro dan Ibu Masriyah, kakak Jaya Riadi, dan saudara lain yang telah memberikan doa, semangat dalam penyusunan Karya Tulis Ilmiah.

11. Ibu Kos Wisma Atika dan Keluarga Kos Wisma Atika yang selama dua tahun menemani dalam suka maupun duka.

12. Teman-teman satu angkatan 2014 dan khususnya teman sekaligus keluarga 3A Damai yang selama tiga tahun telah berbagi suka, duka canda tawa bersama.

13. Azatil Isma, Vina Chusnul, dan Rika yang telah membantu selama proses Penelitian di Yogyakarta.

14. Para Pendoa rahasia yang saya sendiri tidak pernah tau sehingga saya bisa seperti sekarang ini semoga doa baik kembali kepada yang mendoakan saya.

15. Rekan-rekan dan semua pihak yang tidak dapat disebutkan satu persatu.

\section{Daftar Pustaka}

Anad Kumar Singh, Manindra T, Om Prakash dan Mahendra Pratap S, 2012, A Current Review of Cypermethrin-Induced Neurotoxicity and Nigrostriatal Dopaminergic Neurodegeneration, USA : US National Library of Medicine National Instituties og Health, diakses https://www.ncbi.nlm.nih.gov/pmc/article s/PMC3286848/ pada tanggal 09 Januari 2017 pukul 22.21 WIB

Andi Muhadir, 2013, Pedoman Pengendalian Demam Berdarah Dengue Di Indonesia, Jakarta : Kementerian Kesehatan Republik indonesia

Aris Santjaka, 2011, Statistika untuk Penelitian Kesehatan, cetakan pertama, Yogyakarta : Nuha Medika _ , 2013, Pendekatan Model Kausalitas, Malaria, cetakan pertama, Yogyakarta : Nuha Medika , 2016, Zika Dalam Prespektif Vektor dan Upaya Pengendaliannya, Purwokerto : Politeknik Kesehatan Semarang Jurusan Kesehatan Lingkungan Purwokerto

Aris Santjaka, 2016, Proposal Penelitian Pendugaan Resistensi Vektor Melalui Analisis Cohort Densitas Nyamuk Pasca Fogging Focus Demam Berdarah, Semarang : Politeknik Kemenkes Semarang

Badan Pusat Statistik Kabupaten Kudus, 2017, Kepadatan Penduduk menurut Kecamatan di Kabupaten Kudus, 2011 - 2015, Kudus : Badan Pusat Statistik Kabupaten Kudus diakses 
https://kuduskab.bps.go.id/linkTabelStatis /view/id/99 pada tanggal 1 Juni 2017 pukul 12.58 WIB

Bina Ekawati, Dyah Widiastuti, Rahmawati dan Sunaryo, 2015, Peta Status Kerentanan Aedes aegypti (Linn) Terhadapa Insektisida Cypermetrin dan Malathion di Jawa Tengah, Ciamis : Loka Litbang P2B2

Chasan S. Kusnadi, 2006, Pengendalian Vektor dan Binatang Pengganggu ( Vector Control Manual), Makasar : Poltekkes Makasar

Direktorat Jendaral P2PL, 2012, Pedoman Penggunaan Insektisida (Pestisida) Dalam Pengendalian Vektor, Jakarta : Kementerian RI

Elsa Endiyani, 2015, Kohort Densitas Nyamuk pada Fogging Focus Di Desa Kedungrandu Kecamatan Patikraja Kabupaten Banyumas Tahun2015, Purwokerto : Politeknik Kesehatan Semarang Jurusan Kesehatan Lingkungan Purwokerto.

Ferry Mahardika, 2007, Penentuan Status Resistensi Nyamuk Aedes aegypti yang Berasal dari Kecamatan Telanaipu (Jambi) Terhadap Insektisida Malathion dengan Uji Hyati, Skripsi ,Yogyakarta : Universitas Sanata Dharma Yogyakarta,

diakses

https://repository.usd.ac.id/2819/2/028114 030_Full.pdf pada 14 November 2017

Irawan Endy Pratama, 2016, Skripsi “Kohort Evaluasi Nyamuk Dewasa Setelah Pelaksanaan Fogging Focus Di Desa Sidamulih Kecamatan Rawalo Kabupaten Banyumas Tahun 2016”, Purwokerto : Politeknik Kesehatan Semarang Jurusan Kesehatan Lingkungan Purwokerto.

Keputusan Menteri Kesehatan RI, Rencana Strategis Kementerian Kesehatan Tahun 20152019, Jakarta : Kementerian Kesehatan RI diakses

http://www.depkes.go.id/resources/downl oad/info-publik/Renstra-2015.pdf

Kementerian Kesehatan RI, 2016, Wilayah KLB DBD Ada Di 11 Provinsi, Jakarta : Kemenkes RI diakses

http://www.depkes.go.id/article/print/1603 0700001/wilayah-klb-dbd-ada-di-11provinsi.htm Tanggal 11 Januari 2017 pukul 19.31 WIB

Lulu Susanti dan Hasan Boesri, 2012, Jurnal Kesehatan, Pengaruh Insektisida Sipermethrin 100 G/L Terhadap Nyamuk dengan Metode Pengasapan, Penelitian, Semarang : Universitas Negeri Semarang
Muhammad Adam Maulana, 2014, Deskripsi Densitas dan Identifikasi Jenis Nyamuk Di Perumahan Kampus 7 Poltekkes Kemenkes Semarang Kabupaten Banyumas, Purwokerto : Politeknik Kesehatan Semarang Jurusan Kesehatan Lingkungan Purwokerto.

Dinkes Kabupaten Kudus, 2014, Profil Kesehatan Daerah Kabupaten Kudus Tahun 2014, Kudus : Depkes Jawa Tengah diakses http://www.depkes.go.id/resources/downl oad/profil/PROFIL_KAB_KOTA_2014/3 319_Jateng_Kab_Kudus_2014.pdf pada tanggal 1 Juni 2017 pukul 12.52 WIB

Ratna Pramuditya, 2014, Deskripsi Pelaksanaan Pemberantasan Sarang Nyamuk (PSN) Demam Berdarah Dengue (DBD) di Kelurahan Karangpucung Kecamatan Purwokerto Selatan Kabupaten Banyumas Tahun 2014, Karya Tulis Ilmiah, Purwokerto : Kementerian Kesehatan RI Politeknik Kesehatan Semarang Jurusan Kesehatan Lingkungan Purwokerto.

Ririn Y dan Anny V, 2007, Hubungan Kondisi Lingkungan, Kontainer, dan Perilaku Masyarakat dengan Keberadaan Jentik Nyamuk Aedes aegypty di Daerah Endemis BDB Surabaya, Surabaya : UNAIR, diakses http://journal.unair.ac.id/downloadfullpapers-KESLING-1-2-08.pdf pada tanggal 21 Juni 2017 pukul 11.38 WIB

Sayono, dkk, 2012, Distribusi Resistensi Nyamuk Aedes aegypti Terhadap Insektisida Sipermetrin Di Semarang, Journal, di akses http://dinus.ac.id/repository/docs/ajar/rsist ensi_aedes.pdf pada 14 November 2016 pukul 13.00 .

Soedarto, 2012, Demam Berdarah Dengue (Dengue Haemorrahagic Fever), Jakarta : Sagung Seto

Soegeng Soegijanto, 2006, Demam Berdarah Dengue, Edisi 2, Surabaya : Airlangga University Press

Syahrizal, 2016, Status Rresistensi Nyamuk Aedes aegypti Terhadap Malathion di Wilayah Kerja KKP Kelas III Lhokseumawe (Berdasarkan Uji Impregnated Paper dan Biokimia), Semarang : Diponegoro University

Tri Cahyono, 2014, Pedoman Penulisan Proposal Penelitian dan Karya Tulis Ilmiah/Skripsi, edisi revisi tiga, Purwokerto : Politeknik Kesehatan Kemenkes Semarang 
World Heritage Encyclopedia, 2002, Cypermethrin, USA : World Heritage Encyclopedi di akses

http://www.ebooklibrary.org/articles/eng/c ypermethrin pada 09 Januari 2017 pukul 22.12

World Health Organization (WHO), 2016, Test Procedures For Insecticide Resistance Monitoring In Malaria Vector Mosquitoes, 2d Edition.

Windy Diyah Atrikni, 2016, Kohort Evalusi Container Index (CI) Setelah Pelaksanaan Fogging Focus di Desa Sidamulih Kecamatan Rawalo Kabupaten Banyumas Tahun 2016, Karya Tulis Ilmiah, Purwokerto : Politeknik Kesehatan Semarang Jurusan Kesehatan Lingkungan Purwokerto.

Yolamba Ervina, 2012, Uji bioassay dan susceptibility, di akses https://www.scribd.com/doc/117679082/u ji-bioassay-susceptibillity pada Tanggal 20 Januari 2017 pukul 19.45 WIB

Zhejiang Rayfull Chemicals Co.,Ltd, Cypermethrin Material Safety Data Sheet, diakses http://www.rayfull.com/UploadFiles/PDF/ 201369922473.pdf pada tanggal 14 Juli 2017 pukul 0.26 WIB

Hovmand, S. (1995). Fluidized Bed Drying. In Mujumdar, A.S. (Ed.) Handbook of Industrial Drying (pp.195-248). 2nd Ed. New York: Marcel Dekker

Istadi, I. (2006). Development of A Hybrid Artificial Neural Network - Genetic Algorithm for Modelling and Optimization of Dielectric-Barrier Discharge Plasma Reactor. PhD Thesis. Universiti Teknologi Malaysia

Primack, H.S. (1983). Method of Stabilizing Polyvalent Metal Solutions. US Patent No. 4,373,104

Roeva, O. (2012). Real-World Applications of Genetic Algorithm. In International Conference on Chemical and Material Engineering (pp. 25-30). Semarang, Indonesia: Department of Chemical Engineering, Diponegoro University 